\title{
Evidence for the existence of a soul?
}

D. Hartman looks at the work of the painter De Kooning, following the BBCl's Omnibus programme of 21 February 1995

De Kooning is described as "the greatest living painter", at the age of 90 the only survivor of the Abstract Expressionist school which flourished in the United States in the 1950s. But De Kooning, as I learnt in the $\mathrm{BBCl}$ Omnibus introduction, now has Alzheimer's disease. And what is more, he is still painting.

The documentary traced De Kooning's origins in Rotterdam, his arrival in New York as an illegal immigrant in the 1920s, and his early years working as a house painter and a government-employed painter of murals and public works. We saw his simple and beautiful early figurative work, his experimentation alongside Rothko and Pollock with Abstract Expressionism, and his emergence in the 1950s as the colossus, the superstar of the American art world with his violent and disturbing paintings of cadaverous seated women. In the 1960s and 1970s he was overtaken by successive waves of avant garde and became regarded as something of a creative dinosaur by the art world, but he continued to produce paintings which sold for millions of dollars. Then, with the death of his wife in the late 1980s, De Kooning was found to be completely unable to care for himself. A friend found him having not washed or changed for weeks. A diagnosis of Alzheimer's disease was made not long afterwards, and his daughter assumed control of his massive estate, and of him.

Unfortunately we were not shown an interview with the artist. Omnibus did provide vivid accounts by friends and colleagues who describe an old man who evidently has a global aphasia, severe memory impairment and apraxia for many activities. But not, it seems, for painting. Serenely and single-mindedly, De Kooning continues to paint when the materials are provided for him, and produces paintings quite unlike any I have seen emerge from any long-stay psychogeriatric ward. The colours are limpid and distinct, the lines crisp and bold, there seems to be a sense of wholeness and completion about each work. What is missing? There is none of the energy, anguish and tension of his earlier work. It is as if he has forgotten some terrible hurt.

The more important question is: what is still there? Omnibus interviewed a number of art critics and fellow painters who held widely diverging views. The deputy director of the Guggenheim, for example, admitted that she would be "very pleased to procure" his recent works: she believed that they should be judged on artistic (not medical) grounds and were of outstanding quality. An art critic claimed with great feeling that it was plainly impossible for someone with Alzheimer's to produce art, and thought that the very idea was an insult to the art world. An ancient painter, evidently with an old score to settle, also dismissed the idea of art emerging from Alzheimer's disease as "bullshit". A neurologist took a more neutral view: the natural history of Alzheimer's was such that the visual and motor areas were spared until relatively late, so painting may be technically possible. He admitted ignorance of the process which mediates between the eye and the hand. One critic suggested that the higher intellectual functions were probably not necessary for artistic creation, and perhaps even an impedance. "Artists are not as a rule known for their great intellects", as he put it, and it is possible that De Kooning's work is now, for the first time, being expressed in its purest form.

There is some support for the idea that higher cortical functions are not essential for the production of art: the Abstract Expressionists used the technique of "psychic automatism", not unlike psychoanalytic free association, as a way of bypassing the intellect in the production of paintings which portrayed pure and unverbalised emotion. The genius of the artist lies in his or her ability and willingness to access this non-cortical realm of experience, and I believe that this propensity remains intact even after the social self ceases to exist. I am not an artist and I will restrain myself from passing any further judgement on 
the merits of De Kooning's recent work, but as a psychiatrist I feel entitled to discuss De Kooning's soul. Sims has argued for the existence of a spiritual realm which is independent of the physical/medical, and suggests that we should at the very least acknowledge it as a possibility. Something beautiful survives the degeneration of De Kooning's brain: I do not know what this is, but I think that we are obliged to look for the same thing in all of our patients, not least in those with degenerative brain diseases.

D. Hartman, Senior Registrar and Clinical Lecturer, Division of Psychological Medicine, St George's Hospital Medical School, London SW17 ORE 